\title{
The Effectiveness of Local Wisdom Based-Realistic Mathematics Learning to Improve Learners' Characters at State Elementary Schools in Ambon City
}

\author{
Theresia Laurens \\ Universitas Pattimura \\ Ambon, Indonesia \\ tresyalorensa@yahoo.co.id
}

\begin{abstract}
Mathematics learning aims at improving the logical thinking skill in solving problems through a process of reasoning. In fact, learners found the learning materials of mathematics were complex. It can be seen from the understanding and skills of learners in solving mathematical problems involving the concept of numbers. One reason is that the materials are not associated with the reality of everyday life. Mechanistic mathematics learning approach would be meaningless and lead learners to saturation. The abstractness of mathematical objects can be approached through "real world" around the children. Through the reality of children's lives that cannot be separated from an everyday culture which shapes the children's experience, thus, through realistic mathematics learning, the concept of numbers can be explained to learners. Learning the concept of numbers, in this case, fractional numbers and the understanding of the value of place with Local Wisdom Based-Realistic Mathematics Approach (RMA) is said to be effective as the result of learning demonstrated by students taught using this approach is higher than those who are not taught by this approach. The analyses results of Teladan Elementary School show that the value of $t=4.9$ is more than $t$ table $=2.02$ and significance probability of $\alpha=0.00$ is less than 0.05 . In Elementary School of Latuhalat, the analysis shows that the value of $\alpha=0.016$ is less than the value of 0.05 . Average teacher's response towards the aid used was $70 \%$ strongly agreed to indicator determined and $23 \%$ agreed to specified indicators. $80.4 \%$, the application of teachers' lesson plan and $66 \%$ of students showed more than $75 \%$ activities indicators were accomplished. During the learning process, indirectly, learners' characters such as; discipline, cooperation, mutual help, courage, and intelligence were formed.
\end{abstract}

Keywords: Effectiveness, RMA, Local Wisdom, Character

\section{INTRODUCTION}

Mathematics (henceforth; Maths) is one of the disciplines that children have known before they head to school. This is because they are in direct contact with the everyday problems that require mathematical concept even though they have not recognized the mathematical terms yet. Despite the characteristics of mathematical objects are abstract; the teaching and learning, therefore, need to associate with the experience and the daily activities of children, so they can find Maths familiar and useful for life.
Thus Maths learning should be thoroughly done as whole interdisciplinary learning, which means that negotiating Maths with other disciplines, as well as requiring teachers' skills and creativity in designing the lesson plans. In general, teachers are still using mechanistic learning patterns, i.e., the teacher explains the material, gives examples and provides exercises.

At the level of Elementary School (commonly known as "Sekolah Dasar" in Indonesia), the learning patterns are obviously complicated for students who are at the elementary school age, are still at the stage of concrete thinking. The abstract Maths problems (containing symbols, symbols, and formulas) would possibly make the Elementary students feel bored and not interested in learning mathematics, consequently they obtain low scores in Maths learning. Similarly, in learning Maths at a higher level such as junior high or even senior high school, they would definitely have ignorance and hate for Maths. So, teachers should be able to design mathematics learning materials which are familiar with the students and begins with something real or in accordance with the context of their daily lives.

Mathematics learning approach that emphasizes the context and connectivity with real-life of a child is Realistic Mathematics Learning/Approach (RMA). Realistic Mathematics Learning (RML) is an approach to learning Maths adopted from Realistic Mathematics Education (RME), which was developed by the Freudenthal Institute in the Netherlands and has been applied by an Indonesian version [1]. RMA uses a context and a number of activities that emphasize thinking skills and arguing through discussion with fellow students and/or under teacher guidance. RMA helps students find their own mathematical ideas through the learning activities and mathematical problems solving.

Maluku, an archipelago, has a variety of local wisdom that can be used as a context for maths learning. The introduction of the culture and local wisdom for the students from the beginning is essential as a basic introduction to their province so that they are not contaminated with increasingly heavy globalization era. In order for the existence of culture remains intact so teachers need to integrate local wisdom in learning. Local knowledge will be used in this research are Sagu Lempeng or Embal Love which are the staple food of Maluku people taken from Sago Tree and also cassava and kulibia (snails) which are mostly found on the 
shore. Through lesson planning that begins with an analysis of learners' characteristics to the design of teaching aids, learners are expected to understand the concept of abstract mathematics.

The designing lesson that contains a series of activities to achieve the learning objectives need to be supported with the appropriate teaching aids. It is used, in this study, as a model of development that begins by analyzing the students' characteristics to define the suitability of the approach used; designing and developing aids are used as well as are disseminated. The aids used in this study was based on realistic mathematics learning approach that adopts the local wisdom of the typical Maluku food aimed at introducing the values of loving and pride of Maluku culture.

Materials of numbers including fractional numbers are elusive material that students and even teachers have difficulty in teaching it. Therefore, learning equipment is required to make teachers easy to teach the materials and students to understand. Learning equipment was conceived and developed based on the context of the reality of the child which is expected to provide facilities for children in understanding the concept of fractions. The learning equipment is designed using a learning model that can give students the possibility to raise their positive characters when they interact during the learning process.

This paper will discuss the effectiveness of the use of local wisdom based-realistic mathematics learning and teaching aids in raising students' characters.

Education aims at changing the behavior of learners in terms of cognitive, affective and psychomotor. Changes in behavior depending on the processes that occur in the activities in the educational environment. The teacher is a major factor in the process of changing the behavior of learners. The use of media and learning resources need to be prepared with a good planning so that corresponds to the learning objectives. Media and learning resources is an integral part of the teaching and learning aids used by teachers including teaching materials, student worksheets, and assessment instrument. These components are the documents to be prepared and owned by teachers.

With the enactment of the 2013 curriculum emphasized the development of attitudes of learners is needed documents to achieve the goal of learning the curriculum. The concept of fractions is the material being introduced to children at the grade 3 level in the application by using a mechanistic approach. In addition, to the development of learning tools relating to the material fractions, there are other materials that are developed in class 2 SD namely the introduction of the concept of place value material using a set of kulibia. Kulibia (snails) is one order of marine life that is often encountered on the waterfront and is usually used by children as a plaything. The concept developed through kulibia is how to classify the child's understanding of values where the numbers. These materials are part of the children's habits which is not separated from their culture.

According to [2], culture is defined as the whole system of thinking, values, morals, norms, and beliefs recombinant of human society. The system is then used in human lives and resulted in the social system, economic systems, belief systems, knowledge systems, technology, and art and so on.
Local wisdom, in the form of a social order, which creates harmony and dynamism of social life; while ecological wisdom is a righteous act in maintaining the safety of the natural environment. In local wisdom are virtues that grow and shape the character of a nation.

According to [2] said that the character is actually the value of building one's personal kindness and formed due to environmental influences (cultural/indigenous) and manifested in everyday life. According to [2], said that in order to further strengthen the implementation of character education, it has been identified 18 values derived from religion, Pancasila (five principles/Indonesian ideology), culture, and national education goals, such as: ( 1 ) Religious, ( 2 ) Honesty , ( 3 ) Tolerance, ( 4 ) Discipline, ( 5 ) Hard Work, ( 6 ) Creative ( 7 ) Independent, ( 8 ) Democratic ( 9 ) Curiosity, ( 10 ) The spirit of Nationality, ( 11 ) Loving the nation, ( 12 ) Rewarding Achievement , ( 13 ) Friendly / Communicative, ( 14 ) Love of Peace, ( 15 ) Joy of Reading, ( 16 ) the Environment Concern ( 17 ) Social Care, and ( 18 ) Responsibility.

Maluku Island is a rich province in the local wisdom that lives and thrives in society, especially indigenous people. Knowledge and understanding of local knowledge of Maluku are important to be used as a reference in social life. Efforts to preserve and maintain it as part of life should be given a particular award.

Some local moral values of Maluku as such as (1) Values of Fraternity and Kinship (Pela and Gandong) containing a relationship of brotherhood and kinship, (2) Principle of Consultation Consensus in customary governance system as Saniri Negeri and Jou or Soa. All public and Soa Saniri decision must be through consensus. (3) The principle Appreciation Values of Humanity and Life is like eating in Lesa, sitting in Tapalang, eating with Taloi, eat Sagu Salempeng, which intends to be in life should still appreciate and respect the values of humanity (4) Principles of Respect and Recognition against Others, such as Tabia is congratulated as "good day" while the term Upu means the Father, while the term Ina means Mother geared towards women, as a form of respect and appreciation. The principles and values are fading because young people today are less concerned with these values because it is not spoken or taught on a regular basis to be the norm in a socially meaningful.

In line with that, [3] described three kinds of culture-based learning model, namely: (1) Model-based learning culture through traditional games and folk songs. (2) Culture-based learning model through folklore (3) Culture-based learning model through the use of traditional tools. Therefore, in this study will be designed a model designed in the RMA development learning tools based on local wisdom Maluku by integrating the values of character.

Devices that will be produced to accommodate local wisdom Maluku endangered, namely: the class was designed as a country custom and groups formed is called Soa, a table called Tapalang, greeting used is Tabia, greeting for female teachers is Ina and Upu to teachers Male -Eighteen. Chairman of the class was given the title $U p u$ sparks. The group can also be named according to the name of the villages in Maluku, so there will be groups linked Guandong or Pela. This relationship will be used in the class discussion to give each other feedback. The group 
that showed the value of the character will be rewarded with cards containing the character values itself. The design of activity in this study refers to the five characteristics of RME mathematics in Indonesia specialized in Maluku is still cause for concern. One reason is the study of mathematics was implemented partially. Mathematics is taught as a science separate from other sciences, even from student life. In general, teachers are still using mechanistic learning patterns, i.e., the teacher explains the material, giving examples and provides exercises.

Mathematical problems abstract (containing symbols, symbols, and formulas) it will make the elementary students feel bored and not interested in learning mathematics so that the results of their mathematical learning is always low. As a result, when faced with higher mathematics in junior high or high school, they will be increasingly indifferent even hate math. Therefore, teachers should be able to design the elementary mathematics which is familiar with the students and begins with something real or according to the context of students every day.

In Maluku archipelago has a variety of local wisdom that can be used as a context for learning mathematics. Local knowledge will be used in this research are Sagu Lempeng or Embal Love, and cochlear (kulibia). Utilization of local knowledge is expected to grow the character of patriotism, love of food typical of the region, get to know the local culture. The learning process with realistic mathematics approach provides opportunities for students to develop the character of mutual help, cooperation, respect friends, courage, accuracy, and someone behave. If someone behaves honest, responsible, helpful, surely the person manifests a noble character. According to [2], argued that the character is also closely related to the 'personality'. A person can only be called a 'man of character' (a person of character) if its behavior in accordance with moral rules. Thus, education of good character, must involve not only the aspect of "good knowledge" (moral knowing), but also feel good or loving the good (moral feeling) and "good behavior" (moral action).

Learning principles that are used to provide opportunities for learners to recognize and accept the values of the character through the process of thinking, being, and doing that makes them able to interact in daily life through social activities and encourage them to identify themselves as social beings.

\section{METHODS}

This research is a development that produces learning device. Results of further development will be tested to determine their effectiveness through experimental research with design research as follows:

TABLE I. STUDY DESIGN

\begin{tabular}{|l|l|l|}
\hline Group & Treatment & Evaluation \\
\hline Experiments & $\mathrm{T}_{1}$ & Final Test \\
\hline Control & $\mathrm{NT}$ & Final Test \\
\hline
\end{tabular}

T1: Class treatments using a device developed NT: Class Nontreatments for the control class
The research was conducted in SD Teladan and SD Negeri Latuhalat Ambon on September 12 to 15 October 2015 began with a meeting coordination to deal schedule and prepare teachers for using an instrument developed. Subject -class research experimental and control classes each SD Teladan; 53 and 42 students, and SD Negeri Latuhalat each numbered 37 students. The study began by preparing teachers, determining the experimental class, carrying out the preliminary tests to determine the ability of the beginning and the division of the group, implementing the learning and concludes with an evaluation.

Variable used in the research was students' study result that taught by using teaching equipment and the one with no teaching equipment.

The instrument of the research was the test which developed appropriately with the competencies that would be measured; they are the mastery of fraction concept, fraction concept value, serial fraction for SD Negeri Teladan and the understanding of the place of value for SD Negeri Latuhalat. Data collection technique of the research is the test that followed by descriptive data analysis technique and inferential data analysis technique.

Descriptive analysis is used to see the test result of the students by using the formula:

Test Result $=\frac{\text { Students' Score }}{\text { Total Score }} \times 100$,

The students' test result then converted based on the standard reference in Methods of Grading Summative Evaluation written by Bloom, cited in [4].

The inferential data analysis is conducted by using test analysis that went after prerequisite test of homogeneity and normality. In order to test the homogeneity, the F formula of [5] is used.

$$
F_{\text {count }}=\frac{\text { biggest variant }}{\text { smallest variant }}
$$

Hypothetic formula to test homogeneity sample is

$H_{0}$ : sample which has homogeneity sample

$H_{1}$ : sample which has no homogeneity sample

Hypothesis test criteria:

Accept $H_{0}$ if the value of $\mathrm{F}_{\text {count }} \leq \mathrm{F}_{\text {table }}$ or probability result of SPSS output is more than $\alpha=0,05$ value and vice versa.

Data normality test which is conducted by using Chi-Square Statistic Test as written in [5] as follow:

$$
\chi^{2}=\left[\sum_{i=1}^{k} \frac{\left(f_{0}-f_{h}\right)^{2}}{f_{h}}\right]
$$


Hypothetic formula to test data normality is

$H_{0}$ : sample which is from normal distribution of population

$H_{1}$ : sample which is not from normal distribution of population

Criteria for the test:

Accept $H_{0}$ if the value of $\chi^{2} \leq \chi^{2}$ table or probability result of SPSS output is more than $\alpha=0,05$ value and vice versa.

Based on the analysis, it could be concluded that the data is a normal distribution data and it is from homogeny population then followed by inferential statistical analysis or dissimilarity test with the following formula [5]:

$$
t=\frac{\overline{x_{1}}-\overline{x_{2}}}{\sqrt{\frac{\left(n_{1}-1\right) S_{1}{ }^{2}+\left(n_{2}-1\right) S_{2}{ }^{2}}{n_{1}+n_{2}-2}\left(\frac{1}{n_{1}}+\frac{1}{n_{2}}\right)}}
$$

Explanation:

$$
\begin{aligned}
& \mathrm{t}=\text { calculation for } \mathrm{T}-\mathrm{Test} \\
& \bar{x}_{1}=\text { class average grade (treatment group) } \\
& \bar{x}_{2}=\text { control class average grade (treatment group) } \\
& \mathrm{n}_{1}=\text { total sample of experiment class } \\
& \mathrm{n}_{2}=\text { total sample of the control class } \\
& \mathrm{s}_{1}=\text { deviation standard of experiment class } \\
& \mathrm{s}_{2}=\text { deviation standard of control class }
\end{aligned}
$$

After getting $\mathrm{t}$ value, the result will be divided with vale of $(\alpha)=5 \%$ and free degrees $(\mathrm{dk})=\left(n_{1}+n_{2}-2\right)$, using the following criteria:

$\mathrm{H}_{0}$ accepted if $\mathrm{t}_{\text {count }}<\mathrm{t}_{\text {table }}$ or Sig. (2-tailed) on output SPSS $>\alpha$

$\mathrm{H}_{0}$ refused if $\mathrm{t}_{\text {count }} \geq \mathrm{t}_{\text {table }}$ or Sig. (2-tailed) on output SPSS $<\alpha$

The hypothesis of the Research:

$H_{0}$ : There is a difference studying result between students who taught by using developed equipment and students who are not.

$H_{1}$ : There is no difference studying result between students who taught by using developed equipment and students who are not.

\section{RESULTS AND DISCUSSION}

\section{A. The Result of the Research}

The result of the research towards the effectiveness of using realistic math equipment can be seen in the following data. (1). The average result shows that $80.4 \%$ indicators of the lesson plan can be achieved by the teacher, (2). Students' activity in finishing the Work Sheet was good based on the result that showed $>75 \%$ of indicators have been done by $66 \%$ students on average, and (3). There is a difference of the studying result after the use of developed math equipment.

The prerequisite test result showed that data sample from SD Negeri Teladan is normally distributed with significant probability $\alpha=0,889$ and 0,742 more than alpha probability 0,05 and the homogeneity test result showed that the data is a homogeny characteristically based on Fisher Test with significant $\alpha=0,162$ more than 0,05 .

The data sample from SD Negeri Latuhalat is normally distributed with significant probability 0,198 more than alpha probability 0,05 and the homogeneity test result showed that the data is a homogeny characteristically based on Levene Test with significant $\alpha=0,157$ more than 0,05 .

The result of descriptive data showed that there is a difference of studying result of control class sample and experiment class sample. It can be seen in the table below.

\begin{tabular}{|c|c|c|c|}
\hline \multirow[b]{2}{*}{ Qualification } & \multirow[b]{2}{*}{ Result } & \multicolumn{2}{|c|}{ Number of Students } \\
\hline & & $\begin{array}{l}\text { Experiment } \\
\text { Class }\end{array}$ & $\begin{array}{c}\text { Control } \\
\text { Class }\end{array}$ \\
\hline Excellent & $90 \leq \mathrm{x}$ & 4 & - \\
\hline Good & $75 \leq x<90$ & 4 & - \\
\hline Fair & $60 \leq x<75$ & 9 & 3 \\
\hline Enough & $40 \leq x<60$ & 7 & 10 \\
\hline Poor & $\mathrm{x}<40$ & 1 & 8 \\
\hline \multicolumn{2}{|c|}{ Total } & 25 & 21 \\
\hline
\end{tabular}

TABle II. Average GRAdE OF The Final Test

\begin{tabular}{|l|l|l|}
\hline School & $\begin{array}{c}\text { Average Grade } \\
\text { of Control } \\
\text { Class }\end{array}$ & $\begin{array}{c}\text { Average Grade } \\
\text { of Experiment } \\
\text { Class }\end{array}$ \\
\hline SD N. Teladan & 41,67 & 65,20 \\
\hline SD N. Latuhalat & 68,55 & 77,68 \\
\hline
\end{tabular}

Generally, the dissemination of test result after the studying

\begin{tabular}{|c|c|c|c|}
\hline \multirow[b]{2}{*}{ Qualification } & \multirow[b]{2}{*}{ Result } & \multicolumn{2}{|c|}{ Number of Students } \\
\hline & & $\begin{array}{c}\text { Experiment } \\
\text { Class }\end{array}$ & $\begin{array}{c}\text { Control } \\
\text { Class }\end{array}$ \\
\hline Excellent & $90 \leq x$ & - & - \\
\hline Good & $75 \leq x<90$ & 11 & 3 \\
\hline Fair & $60 \leq x<75$ & 4 & 13 \\
\hline Enough & $40 \leq x<60$ & 1 & 1 \\
\hline Poor & $\mathrm{x}<40$ & - & - \\
\hline \multicolumn{2}{|c|}{ Total } & 17 & 17 \\
\hline
\end{tabular}
process of both school are grouped based on grade reference from the table below.

TABEL III. THE GROUPING OF THE FINAL TEST RESULT OF SD NEGERI TELADAN

TABEL IV. THE GROUPING OF THE FINAL TEST RESULT OF SD NEGERI LATUHALAT

In order to know the significant difference of studying result as shown in Table III, the hypothesis was made to test the truth. Based on hypothesis test result, it showed that there is no difference of studying result of both schools. 
This is proofed by hypothesis testing based on the results of the statistical analysis that are made to the data of the students of SD Negeri Teladan and SD Negeri Latuhalat learning outcomes. The result of SD Negeri Teladan shows that the value of $t=4.9$ is more than the value $\mathrm{t}$ table $=2.02$ and the probability of significance of $\alpha=0.00$ is less than $\alpha=0.05$. For SD Negeri Latuhalat, the analysis shows that the value of $t=2.54$ is more than the value $t$ table $=1.74$ and a significance probability value $\alpha=0.016$ less than the value of $\alpha=0.05$, the average teachers' response to the device used is $70 \%$ really agreed and $23 \%$ agreed based on specified indicators. The achievement of the indicators in the lesson plan is $80.4 \%$ and $66 \%$ of students showed more than $75 \%$ activity indicator is accomplished.

\section{B. Discussion}

The learning plan is designed in the form of syllabus and lesson plans that refers to the content standards. Moreover, in lesson planning, media and learning resources, assessment tools, and learning scenarios are also prepared. The observation of teachers' activities during learning using the developed learning tools indicates that not all indicators of the learning process undertaken by teachers, despite the effectiveness requirements have been met. The learning activity is the implementation of Lesson Plan (RPP) includes introductory, core and closing. The learning activities observed showed that in general, teachers already implemented the learning well.

In the application of realistic mathematics, the teacher provides good responses to the device. Based on the responses provided as well as the observation of learning activities, it can be said that the developed learning tools can be used in the learning process.

To determine the effectiveness of the user device, an experimental research organized. The result showed that there were differences in learning outcomes between students taught using realistic mathematics learning tool based on local knowledge and the students who were taught using conventional learning. This difference indicates that the developed learning tools give a broad space for learners in constructing knowledge. This can be seen in the lesson plans prepared and the learning approaches used.

In the process of learning, besides knowing the learning activities created by teachers, the students were also given activities to develop their higher thinking skills level, for example by working on the students' worksheet. In the process, they also develop the character of concerning about the environment, the character of cooperation, mutual help, tidiness, etc. The character development designed in the Lesson Plan needs to pay attention to the methods and strategies and learning approaches used. Character development would be helpful if the learning activity designed allows the creativity of learners. Students are asked to find the concept of equivalent fractions using the collage form of "EMBAL love" in completing the worksheet. Here, the activities conducted are cutting out and sticking to compare parts of EMBAL that led to the invention of the concept of equivalent fractions and order fractions. The activities are made in the form of cooperation through interaction within the group. Furthermore, it develops knowledge domain and also the domain of skills as part of the learning objectives for these two domains have differences and similarities of learning activities.

The characteristic of learning activity in knowledge domain has differences and similarities with learning activities in the domain of skills. To encourage students to think creatively and contextually, the lesson plan that can be used is through the realistic mathematics learning. This is because the characteristics of realistic mathematics learning are context, interactivity, and contributions. This is in accordance with the opinion of de Lange and Gravimeter in Laurens (2012) that the characteristics of mathematics learning realistic starting from a context (the use of context), using a model (the use models, bridging by vertical instruments), using the contributions of students (student contribution), interactivity (interactivity) and the linkage (intertwining). The use of model "EMBAL love" or EMBAL flower consists of five sections which are arranged as a whole and observed by learners through a process of reasoning to find the concept of equivalent fractions and order fractions. For game kulibia, the learners are directed to find the concept of place value. Thus, the material taught through learning that encourages creative thinking provides opportunities for learners to construct knowledge and foster positive habits that lead to the formation of character.

In addition to the core activities of learning, the final activity also ended with providing an evaluation. The instrument used is an instrument that was developed in this research. The activity that occurs in this section is teacher and students do the reflection and make conclusions about the material being taught and give homework as feedback and enrichment.

\section{CONCLUSION}

Effective learning offers a positive contribution to the learners' mastery of the material being studied. The effectiveness criteria identified through the achievement of learning objectives also can be seen in the implementation of the lesson plan. Based on the analysis of the observations of learning activities using realistic mathematics learning devices based on local wisdom and students activity in learning realistic mathematics as well as the differences in learning outcomes between the control group and the experimental class, it can be concluded that the study of mathematics developed is effective to be used in mathematics learning, especially in the concept of fractions and place value. The device also gives opportunities for students' character development.

\section{REFERENCES}

[1] Sembiring, 2007, Dekade Matematika Realisttik, P4MRI, Bandung

[2] Kemendiknas, 2010, Kerangka Acuan Pendikan karakter Tahun Anggran, 2010 Direktorat Ketenagaan Dirjen Dikti, Jakarta.

[3] Sutarno. 2008. Pendidikan Multikultural. Jakarta: Direktorat Jendral Pendidikan Tinggi Departemen Pendidikan Nasional.

[4] Ratumanan T.G dan Laurens, Th (2011), Evaluasi Proses dan Hasil Belajar, Unipress Surabaya.

[5] Sugyono, 2009, Penelitian Pendidikan, Alfabeta, Bandung 